\title{
Development of Double-Coil Drive Type IH Cooking Heater Corresponding to All-Metals
}

\author{
Hironobu Yonemori Student Member (Kogakuin University, yonemori@u01.itscom.net) \\ Miki KobayashiＭember (Kogakuin University, ct67326@ns.kogakuin.ac.jp)
}

Keywords: IH cooking heater, double-coil, heating coil, all-metal, eddy current

This paper discusses the development of a new type IH cooking heater that uses the double-coil. Adoption of double-coil is the main point of this new IH cooking heater. Fig. 1. shows the model of new type IH cooking heater corresponding to the all-metal. Doublecoil is arranged under metal load. Fig. 2. shows coil current waveforms and eddy current waveform. Current whose phase differs 180 degrees with each other is supplied to a pair of this double-coil. As the result, high frequency-2 times that of supplying current frequency-eddy current flows in the metal load. Using this new technique mentioned above, heating the non-magnetic metals that had been difficult to heat became possible. In order to prove the predominance of developed method, it compar we compared the temperature rise with existing method and developed method. Fig. 3. shows temperature rise by existing method. Remarkable rise in temperature is observed for the stainless, because its electrical resistivity is high. But, as for the aluminum and the copper, temperature rise is very small because these metal have small resistivity. Fig. 4.

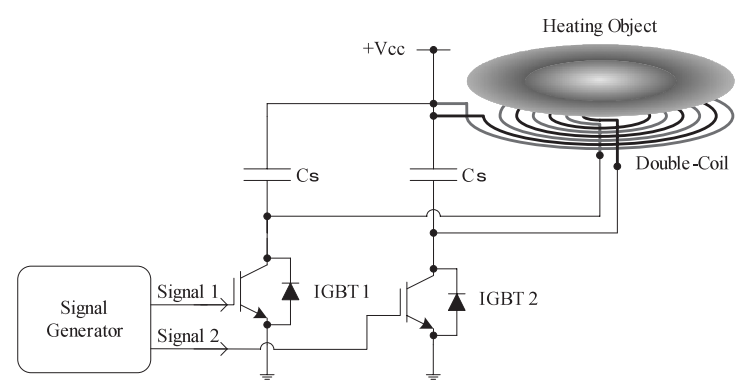

Fig. 1. System model

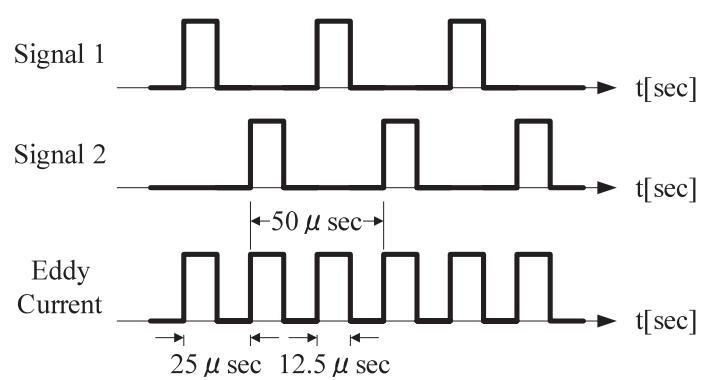

Fig. 2. Coil current waveforms and eddy current waveform shows temperature rise by the developed method. It is clearly shown that all metal loads attain temperature rise. As for the stainless, the highest temperature rise is $15^{\circ} \mathrm{C}$ higher than the existing method. Furthermore, as for the aluminum which is almost not heated by the existing method the highest temperature rise shows $60^{\circ} \mathrm{C}$. And the copper exceeded $45^{\circ} \mathrm{C}$. From these results obtained here, effectiveness of the developed system is maid clear. By the developed method, we can double eddy current freqency very simply. In other words, it is the epoch-making method which can be applied to the induction heating apparatus for industry, not just the IH cooking heater. In this time, heating characteristics of developed method is made clear. As a conclusion, we reported the fact that the nonmagnetic metals can be heated by the developed method.

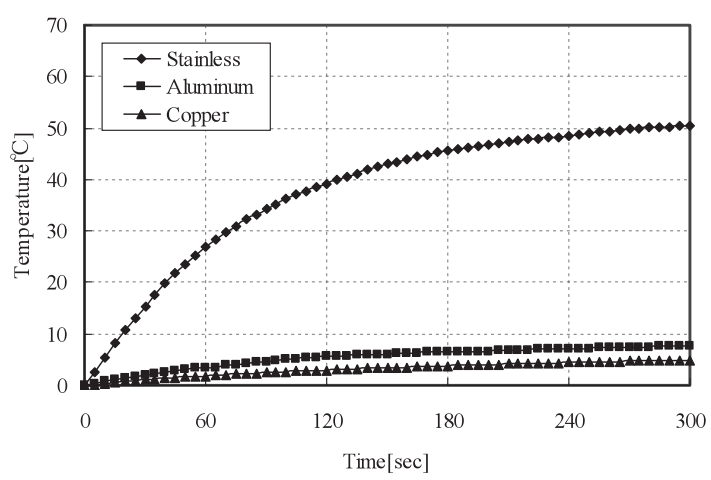

Fig. 3. Temperature rise by existing method (average)

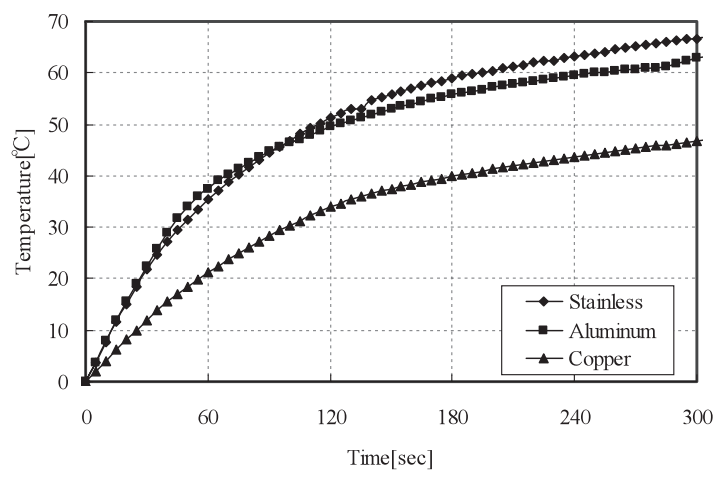

Fig. 4. Temperature rise by developed method (average) 


\title{
二重コイル駆動型オールメタル対応 IH クッキングヒータ
}

\author{
学生員 米盛 弘信* 正 員 小林 幹*
}

\section{Development of Double-Coil Drive Type IH Cooking Heater Corresponding to All-Metals}

\author{
Hironobu Yonemori*, Student Member, Miki Kobayashi*, Member
}

This paper discusses the development of a new type IH cooking heater that uses the double-coil. Adoption of double-coil is the main point of this new IH cooking heater. Current whose phase differs 180 degrees with each other is supplied to a pair of this double-coil. As the result, high frequency -2 times that of supplying current frequency — eddy current flows in the metal load. Using this new technique mentioned above, heating the non-magnetic metals that had been difficult to heat became possible. In this paper, heating characteristics of developed method is made clear. As a conclusion, we report the fact that it has been made possible to heating the non-magnetic metals.

キーワード：IH クッキングヒータ, 二重コイル, 加熱コイル, オールメタル, 渦電流

Keywords: IH cooking heater, double-coil, heating coil, all-metal, eddy current

\section{1.はじめに}

近年，火を使わない調理器具として誘導加熱を利用した IH (Induction Heating) クッキングヒータの需要が急増し ている。これは, 高効率, 安全性, 快適性, 清掃性が優れ ているため一般家庭に広く浸透したためと考えられる。さ らに，従来は専用の鉄鍋しか使用できなかったが，最近は オールメタル対応 ${ }^{(1)(2)}$ の IH クッキングヒータが商品化され ており普及に拍車をかけている。

オールメタル対応機種が開発される以前は，アルミニウ ム等の非磁性金属の加熱は不可能であった。これは,アル ミニウムや銅などの非磁性金属の抵抗率が鉄や磁性ステン レス等の金属に比べて小さいことが最大の原因である。抵 抗率が小さいと鍋に渦電流が流れても大きなジュール熱が 発生せず，調理に必要な火力が得られない。これを克服す るには，鍋底の表皮効果を顕著にして金属の表面にだけ電 流を流すのがひとつの解決手段である。つまり，オールメ タル対応 IH クッキングヒータの開発は渦電流の高周波化 が命題になっている。しかし, 渦電流を高周波化するため には磁束を発生させる加熱コイルに高周波電流を流さなけ ればならない。このことは，加熱コイルの表皮効果も増大 することになり，見かけ上の抵抗が増えるために損失が増 加してしまう。これらの諸問題を解決して 2002 年 11 月に

\footnotetext{
* 工学院大学大学院工学研究科電気 . 電子工学専攻

₹ 163-8677 東京都新宿区西新宿 1-24-2

Graduate School of Engineering, Electrical Engineering and

Electronics, Kogakuin University

1-24-2, Nishi-shinjuku, Shinjuku-ku, Tokyo 163-8677
}

世界で初めてオールメタル対応 IH クッキングヒータが商 品化 ${ }^{(3)}$ された。このことによって, 家庭の調理場は新たな 世紀を迎えたといっても過言ではない。

このような社会的背景を受けて，筆者らは今後さらに需 要が増加すると見込まれるオールメタル対応 IH クッキン グヒータの新たな構成法(4)(5) を考案した。これは, 加熱コ イルやスイッチング素子は従来のままで渦電流だけを高周 波化するという新しい見地にたったものである。高周波渦 電流の生成は, 加熱コイルを二重にしてそれぞれに位相を 180 度ずらした電流を流すことで発生させる。このことに より，スイッチング周波数は低いままで加熱対象の金属に はスイッチング周波数の 2 倍の高周波渦電流を誘起させる ことが可能である。高周波渦電流の生成によって, 加熱金 属の表皮効果が顕著になり, 今まで加熱しにくかったアル ミニウムや銅といった非磁性金属や低抵抗率金属の加熱が 可能となる。すなわち, 従来から使用されている家庭用調 理器具を金属の種類による制約を受けずに使えるため, 利 便性が向上して応用範囲がさらに広がる。また，提案法と 現在あるオールメタル対応化技術(1)(2)を組み合わせればよ り一層の加熱特性の向上が見达まれる。これは, IH クッキ ングヒータに限らず様々な用途の誘導加熱装置にも応用で きる新たな構成法である。

本論文では，この提案法の効果を確かめるために市販さ れている卓上型 IH クッキングヒータ†の回路構成を利用し, オールメタル非対応の従来型と従来型の回路を 2 組み用い

\footnotetext{
†卓上型 $100 \mathrm{~V}$ タイプは $\mathrm{IH}$ 調理器ということが多いが，ここでは誘 導加熱調理器を総称して IH クッキングヒータとよぶ。
} 
て構成した提案する新システムの加熱特性を実験的に確認 してその性能を評価する。この結果, 従来技術を応用でき る新システムであるオールメタル対応 IH クッキングヒー 夕の実現が可能であることが認められたので報告する。

\section{2. 従来のIH クッキングヒータ}

図 1 に IH クッキングヒータの加熱原理図を示す。IH クッ キングヒータは, 高周波インバータから約 $20 \mathrm{kHz}$ の高周波 電流を加熱コイルに流すことで，高周波磁界を発生し，鍋 自体を直接加熱するものである。磁界を受けた鍋底は磁界 を打ち消す方向に渦電流が流れる。そして，鍋の電気抵抗 $\times$ 渦電流の 2 乗なるジュール熱が発生して鍋自体が発熱す る。鍋の加熱電力は次式で表される。

$$
P \propto \sqrt{\rho \mu f}(N I)^{2}
$$

ただし， $\rho:$ 鍋の抵抗率， $\mu$ : 鍋の比透磁率， $f:$ 加熱周 波数, $N$ : 加熱コイルのターン数, $I:$ 加熱コイルの電流で ある。

(1) 式より，抵抗率が低いアルミ鍋等を従来と同じよう に発熱させるには，加熱コイルに流れる電流の周波数また は加熱コイルのターン数, 加熱コイルの電流を増加させる 必要がある。ここで，コイルに流す電流量には限界がある ので, 文献(1), (2) では電流周波数と加熱コイルに注目し ている。電流周波数を従来の 3 倍である $60 \mathrm{kHz}$ にし, 線 径 $\Phi 0.05 \mathrm{~mm}$ を 1600 本束ねた加熱コイルでオールメタル 対応を実現している。高周波電流の生成は, 素子の損失を 考慮してスイッチング周波数は $20 \mathrm{kHz}$ のままで 3 倍化共 振技術を使い $60 \mathrm{kHz}$ を実現している。現在ではさらに改 良が進み, 電流周波数を $90 \mathrm{kHz}$ で駆動している。加熱コイ ルの損失は，高周波電流による表皮効果が問題となるため 線径を細くして本数を多くすることで解決している。

また，加熱対象の金属からみれば電流の高周波化によっ て表皮効果が顕著になり鍋底に誘起される渦電流の流路厚 みが薄くなる。この結果, 見かけの抵抗が増加して加熱が 促進される。

\section{3. オールメタル対応装置開発の問題点}

抵抗率の低い金属や非磁性金属を加熱できるオールメ夕 ル対応の IH クッキングヒータを構成するには様々な課題 があり，一部で解決策が見出されている。ここで，オール

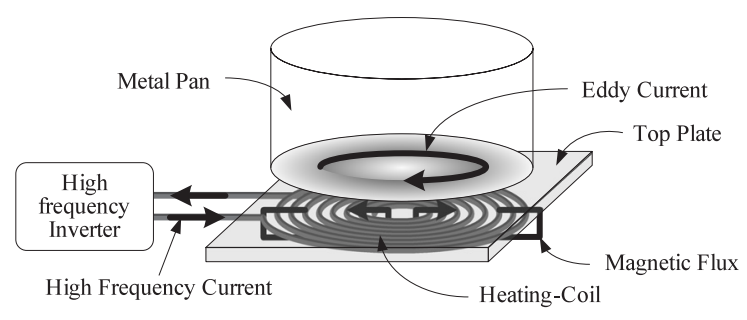

図 1 IH の加熱原理

Fig. 1. Heating principle of $\mathrm{IH}$.
メタル対応化の問題点を列挙する。

(1) 高速スイッチングによる半導体パワー素子の損失 $\Rightarrow$ スイッチング周波数を上げると素子の損失が多く なる。

（2）コイルの表皮効果

$\Rightarrow$ 加熱コイルに流す電流を高周波化すると, 加熱コ イルの表皮効果も大きくなり，見かけ上の抵抗が 増えて損失が増大する。

したがって，スイッチング損失や加熱コイルの損失を抑 えながらも金属負荷に高周波の渦電流を生成することが課 題となる。つまり，スイッチング周波数の非高周波化と渦 電流周波数の高周波化というトレードオフの関係を満足で きれば IH クッキングヒータの高効率化が達成できる。

\section{4. 提案するシステム構成}

スイッチング素子として IGBT を使用するが，そのスイッ チング周波数を増加させるとスイッチング損失が問題とな る。また, 従来の線径のコイルで $20 \mathrm{kHz}$ を超える高周波 電流を流すとコイルの表皮効果が問題となる。そこで， ス イッチング周波数と加熱コイルは従来のままで, 加熱に直 接関係する渦電流の高周波化に着目した。

図 2 にオールメタル対応 IH クッキングヒータの新たな構 成法のモデルを示す。金属負荷の下部に二重コイルを配置 し，それぞれに位相の異なる電流を流すことで電流周波数 の 2 倍の高周波磁界を発生させる。金属負荷には，この高 周波磁界と同じ周波数の渦電流が誘導される。なお, コイ ルと並列に接続しているコンデンサ $C_{S}$ はゼロ電圧スイッ チング（ZVS）を行うための共振用コンデンサである。以 後, 細部について解説する。

図 3 に考案した二重コイルのモデル図を示す。図 3 から 分かるように同一平面内に 2 つのイルを配置している。 この 2 つのコイを 180 度位相の異なる電流パルスで駆動 することにより, 鍋底に誘導される渦電流の周波数の増大 を図る。また，この二重コイルは同一平面であるほか，上 下に重ねた場合や同心円で二重に配置する場合も考えられ る。つまり，提案法に用いる二重コイルは金属負荷に対し て単にコイルを二重に配置することで簡単に構成できる。

図 4 に二重コイルに流す電流波形と鍋底に誘導される高

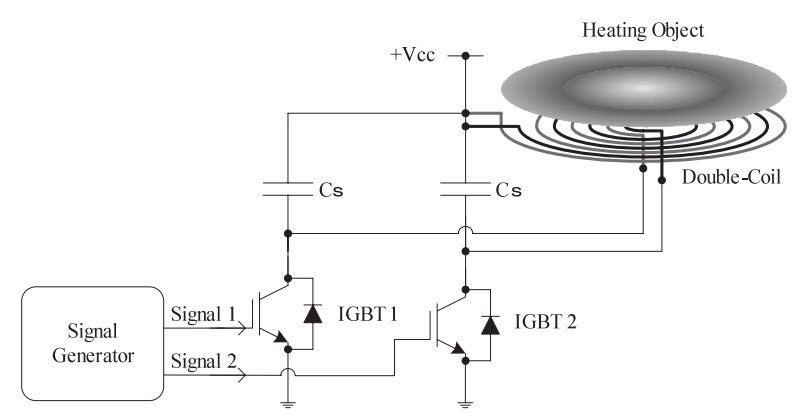

図 2 システム構成モデル

Fig. 2. System model. 


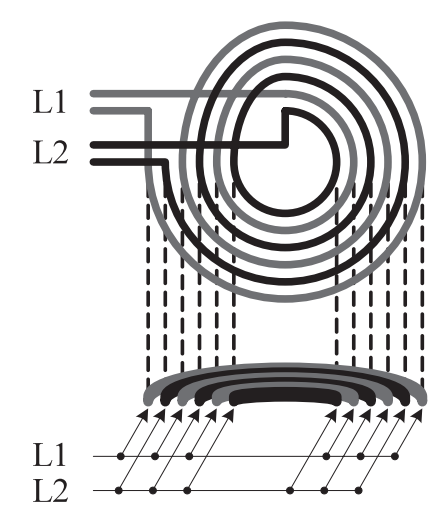

図 3 二重コイルのモデル図

Fig. 3. Model of double-coil.

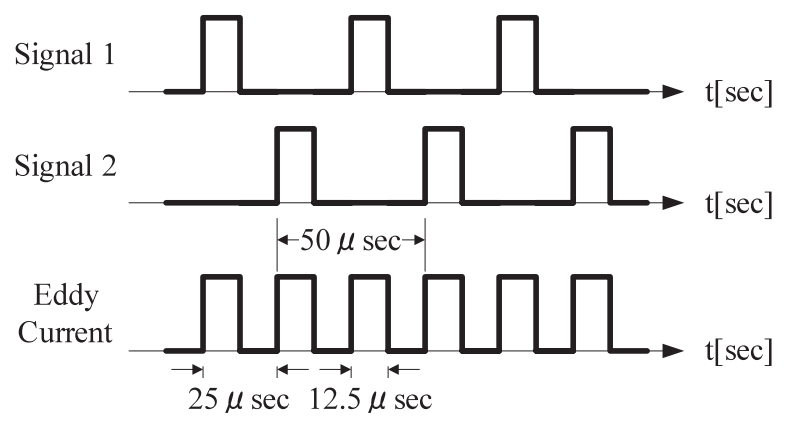

図 4 コイル電流波形と渦電流波形

Fig. 4. Coil current waveforms and eddy current waveform.

周波渦電流の波形を示す。図 4 のようにコイルに流す電流 の位相を 180 度ずらすことでIGBT 自体のスイッチング周 波数を上げることなく，高周波渦電流の誘導が実現できる。 また，この動作であれば従来から研究されているソフトス イッチングの技術等 ${ }^{(6)}$ が利用できる。さらに，3 倍化共振 技術を利用すれば，今以上の高周波化が実現できる。

\section{5. 実験方法}

図 5 と図 6 に従来法と提案法の加熱特性を測るための実 験回路を示す。ここでは比較の便宜上，図 5 の回路構成は 実際に市販されている卓上型 IH クッキングヒータと同一の ものを用いた。加熱コイルだけは，製品で使用されている ものを流用している。回路素子は，加熱コイルのインダク タンスにあわせて設計した。そして，図 6 に示す提案法は 従来法との比較のために既存の回路を 2 組み用いて構成し た。従来法の入力信号はデューティー比 $50 \%$ の $20 \mathrm{kHz}$ 方 形波を用いた。提案法は図 4 に示すデューティー比 $25 \%$ の $20 \mathrm{kHz}$ 方形波を入力信号として IGBT に加えてコイル電流 を流した。このとき，加熱コイルのターン数は従来法も提 案法も同一である。ここで，磁束の発生に関係する電源電 流を基準とし，システムに加える電流を $4 \mathrm{~A}$ 一定の電流源 で駆動する。加熱コイルと並列に接続しているコンデンサ は共振用コンデンサであり, 電磁調理器用 HFC-MD タイプ $0.32 \mu \mathrm{F}$ を用いている。また，スイッチング素子の IGBT は

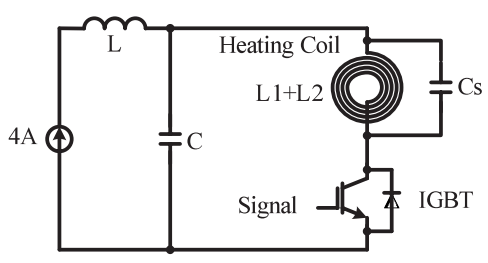

図 5 従来法の実験回路

Fig. 5. Experimental circuit of existing method.

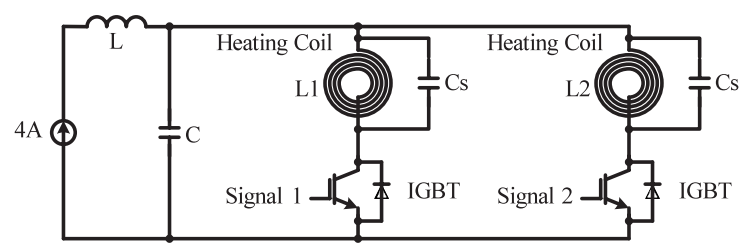

図 6 提案法の実験回路

Fig. 6. Experimental circuit of developed method.

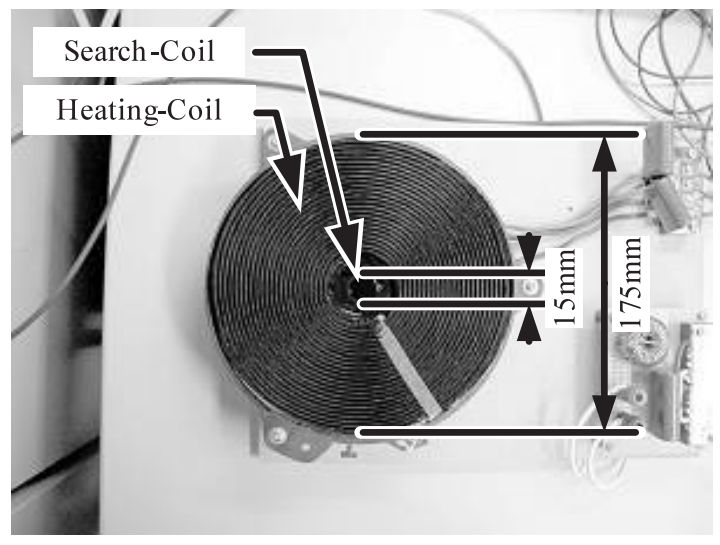

図 7 加熱コイルの外観

Fig. 7. Appearance of heating-coil.

電磁調理器に適した“CT60AM-18F”を採用している。信 号生成部はマイクロコンピュータ“PIC16F84A”で構成し, 基準クロックは $20 \mathrm{MHz}$ のセラロックを使用している。そ の出力を IGBT ゲート駆動用フォトカプラ“TLP250”で絶 縁して IGBT に加えている。なお，入力側のコイルとコン デンサは力率改善用のフィルタであり $, \mathrm{L}=154.5 \mu \mathrm{H}, \mathrm{C}=$ $6 \mu \mathrm{F}$ である。

図 7 に使用する加熱コイルの外観を示す。これは, 市販 の卓上用 IH クッキングヒータで使用しているものと同一で ある。この加熱コイルは， $0.5 \mathrm{~mm}$ の線を 31 本束ねてある リッツ線を平面円形状に 23 回巻いたもので, 直径は $175 \mathrm{~mm}$ である。この加熱コイルを二重コイルとして扱うために， $\mathrm{L} 1=15$ 本 $+\mathrm{L} 2=15$ 本に分けて提案法の加熱コイルとし た。さらに, 高周波磁界の発生を確認するために加熱コイ ルの中心にサーチコイルを配置した。このサーチコイルは, $0.2 \mathrm{~mm}$ のエナメル線を 10 回巻いて構成しており, 直径は $15 \mathrm{~mm}$ である。また, サーチコイルには $10 \mathrm{k} \Omega$ を並列に接 続してあり，ここではこの抵抗の端子電圧を測定している。

図 8 に金属負荷の温度を観測する測定図を示す。温度を 


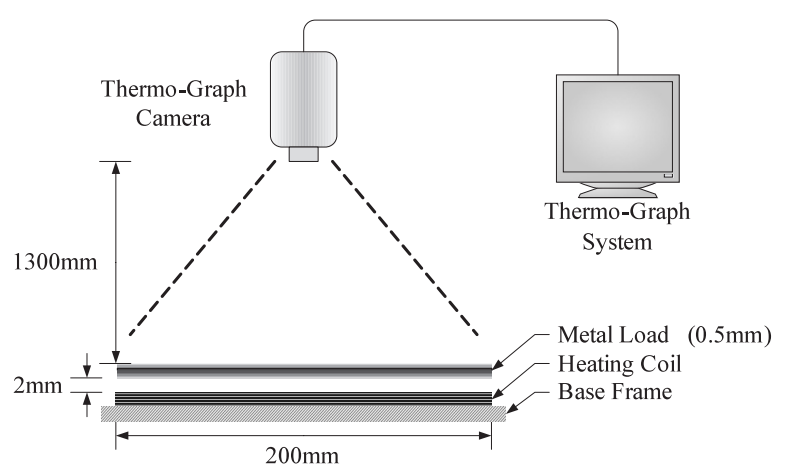

図 8 加熱特性の測定図

Fig. 8. Measurement figure of heating characteristic.

観測するために用いたサーモグラフは，日本アビオニクス 社製サーモグラフ TVS-2000MkII である。このサーモグラ フのカメラ部を金属負荷上 $1300 \mathrm{~mm}$ の位置に配置した。カ メラで取得したデータは観測器本体へ送られ, 温度がカラー でリアルタイムに表示される。加熱対象は, 非磁性ステン レス-SUS304，アルミニウム-A1015，銅-C1100を使用し た。これら金属は厚み $0.5 \mathrm{~mm}$ の金属板を直径 $200 \mathrm{~mm}$ の 円形に切り出して金属負荷とした。加熱コイルと金属負荷 の間は $2 \mathrm{~mm}$ の間隔をとった。なお，サーモグラフで正確 に温度が測定できるように，金属負荷表面に耐熱黒塗料を 塗布してある。この測定システムで時間経過に対する金属 負荷の温度上昇を観測する。

以上のシステム構成により，高周波磁界の発生を確認し， 加熱時間と加熱特性の実験を行う。

\section{6. 実験結果}

〈6・1〉 高周波磁界の発生 サーチコイルを用いて, 高 周波磁界の発生を確認する。オシロスコープによりサーチ コイルの電圧波形を観測した。図 9 に駆動信号と各種金属 負荷についてのサーチコイル電圧波形を示す。(a)の駆動信 号は, マイクロコンピュータの出力信号である。この信号を フォトカプラで絶縁して IGBT に加えている。(b) から (d) はそれぞれの金属負荷に対するサーチコイル電圧波形であ る。どの金属負荷に対しても周波数が約 $40 \mathrm{kHz}$ となってい る。ここでは，二重コイルにデューティー比 $25 \%$ の $20 \mathrm{kHz}$ 方形波信号を 180 度の位相差をもたせて加えた場合，合成 磁界の周波数がスイッチング周波数の 2 倍になっているこ とを確認できる。また，アルミニウムと銅はほぼ同じ波形 が得られたが，ステンレスでは電圧が小さいことを確認で きる。

以上より，どの金属負荷においてもスイッチング周波数 の 2 倍である高周波磁界の発生を確認できた。このことに より，金属負荷の表皮効果が顕著になり，低抵抗率金属の 加熱を増強できる見达みが得られた。

〈6・2 〉 非磁性金属板の加熱試験 3 種類の金属負荷の 加熱特性を測定する。図 8 に示すように金属負荷上にサー モグラフをセットする。この測定構成でシステムに加える

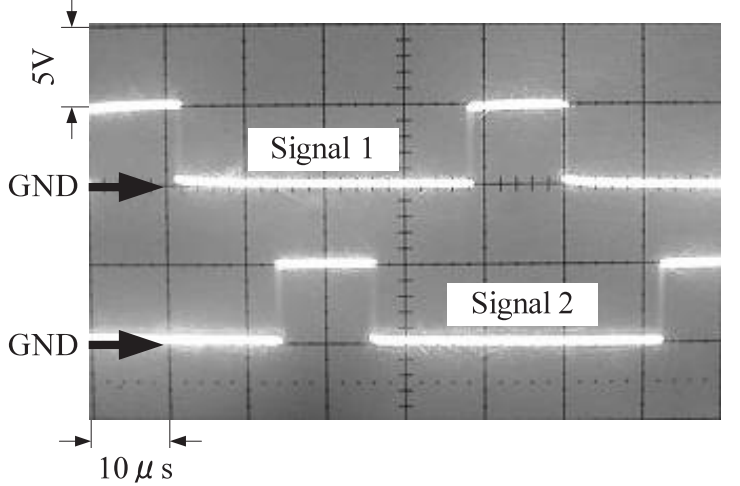

(a) Drive Signals

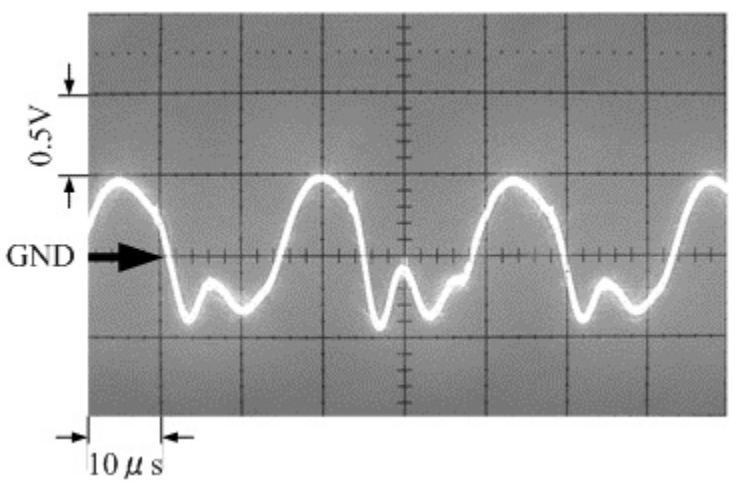

(b) Stainless-SUS304

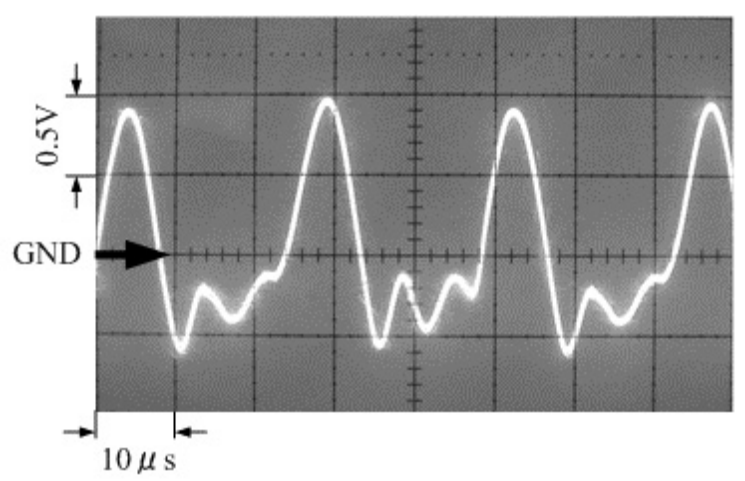

(c) Aluminum-A1015

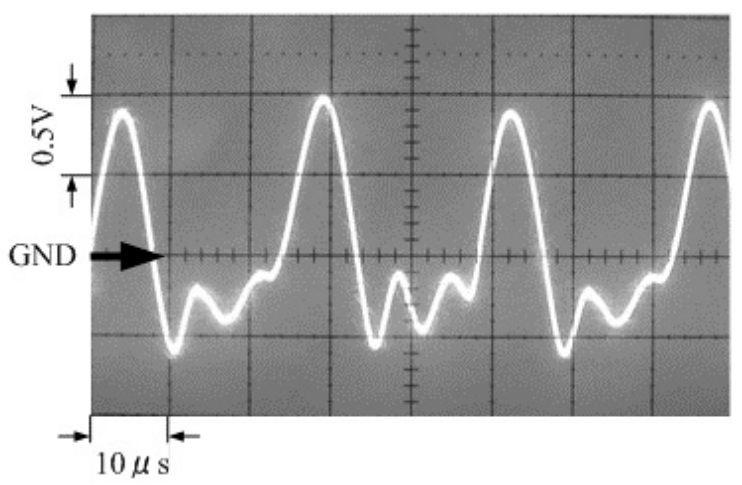

(d) Copper-C1100

図 9 駆動信号と各種金属負荷における サーチコイル波形

Fig. 9. Drive signals and search coil waveform of various metal loads. 
電流を $4 \mathrm{~A}$ 一定として「時間一加熱特性」を測定した。この とき 5 秒ごとに温度を記録した。

図 10 に各種金属負荷の温度分布をサーモグラフ処理用 ソフトウェア PE Professional Version 3.12 を用いて 3D 表 示したものを示す。これは，温度が高いほど山を高く表示 している。図 10 では，加熱開始 1 分後の金属負荷上の温 度分布を示している。

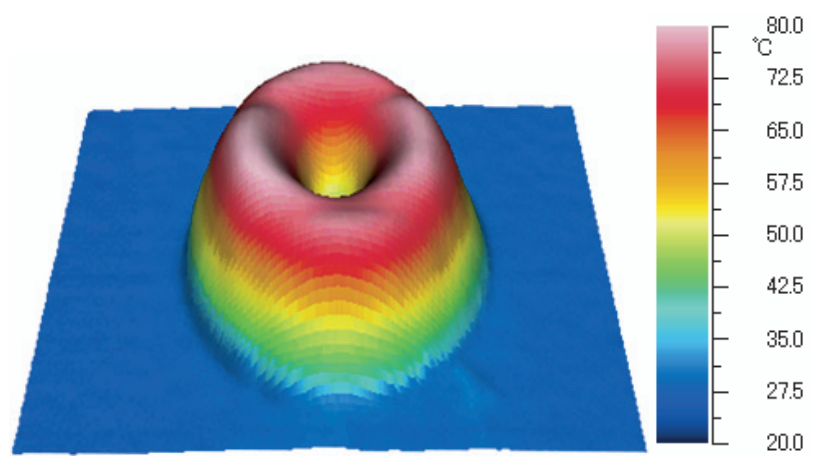

(a) Stainless-SUS304

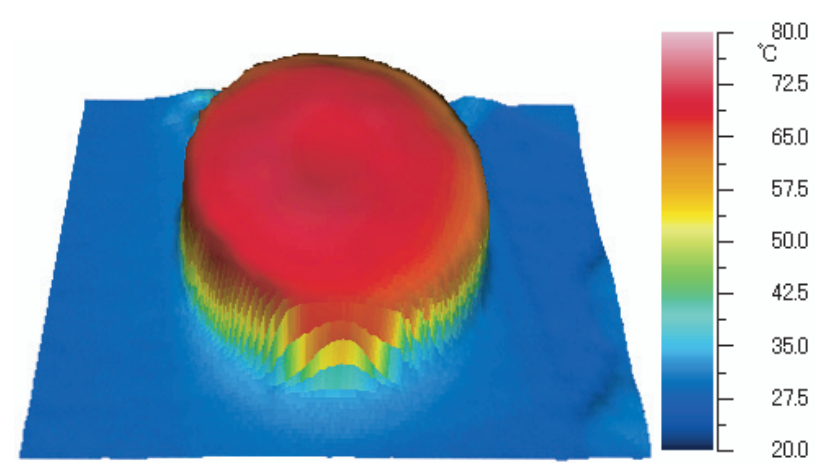

(b) Aluminum-A1015

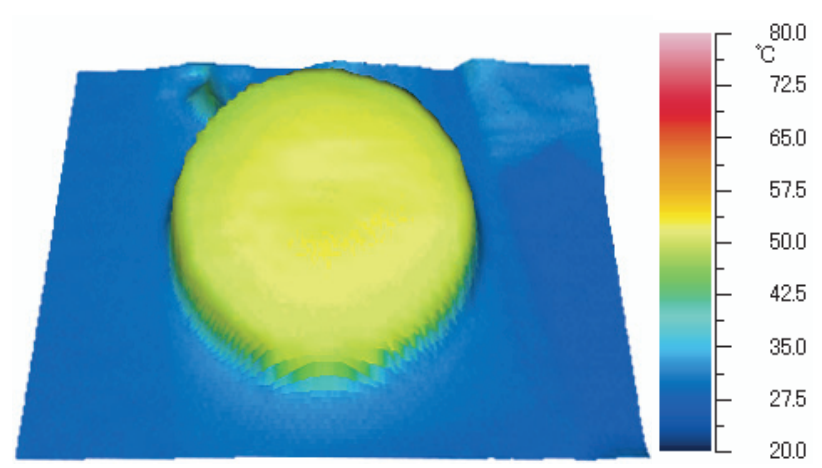

(c) Copper- $\mathrm{C} 1100$

図 10 サーモグラフによる温度分布

Fig. 10. Temperature distribution by thermo-graph.
ステンレスは，抵抗率が大きく熱伝導率が小さいので渦 電流の流れる同心円状に熱が分布していることが分かる。 一方，アルミニウムは加熱初期段階では熱が同心円状に分 布するが，ステンレスに比べて熱伝導率が大きいので，短 時間で金属負荷全体へ温度が分布している。銅はアルミニ ウムに比べて抵抗率と比熱が小さく熱伝導率が大きいので 温度が均一に分布している。しかし，アルミニウムほどの 温度上昇は見られなかった。これは，アルミニウムより銅 のほうが同じ周波数における表皮厚が厚いためと考えられ る。つまり，銅はアルミニウムより電流の流れる体積が大 きいため抵抗が小さく，大きなジュール熱を発生していな いと評価される。

以上により，アルミニウムと銅はステンレスに比べて熱 伝導率が大きいので局所的に加熱せず，調理時の焦げ付き 等が少なくなると思われる。なお，表 1 に各種金属の比熱 と熱伝導率等の物理定数を示す。ここで, 表皮厚は $40 \mathrm{kHz}$ のときの值を示した。

図 11 に図 10 の 3D 温度分布を PE Professional Version 3.12 を用いて解析した結果を示す。このグラフでは, 各種 金属負荷面内の最高温度, 平均温度, 最低温度の 3 段階に 分けてグラフ化している。また, 縦軸は温度の上昇量を示 しており，加熱初期温度を $0^{\circ} \mathrm{C}$ とて表示している。

(a)のステンレスは最高温度上昇が 300 秒到達時刻に約 $95^{\circ} \mathrm{C}$ まで達している。しかし, 熱伝導率が小さいので熱が 局所的に分布しており平均温度との開きが大きい。一方, (b) のアルミニウムはステンレスに比べて熱伝導率が大きい ので最高温度と平均温度との開きが少なく, 均一に温度が 分布しているのが分かる。また，(c)の銅も同様に熱伝導率 が大きいので最高温度と平均温度との開きが少なくなって いる。しかし，アルミニウムより表皮厚が厚いので抵抗が 小さく温度上昇は一番低くなっている。

以上により，ステンレスは同心円状に局所的な加熱特性 を示し，アルミニウムと銅は金属負荷全体が均一に加熱す るという結果が得られた。このような特性の違いを活用す れば，料理の種類に応じて鍋の種類を選択できる可能性が 生まれる。

$\langle\mathbf{6} \cdot 3\rangle$ 従来法と提案法の比較 提案法の優位性を証 明するためにオールメタル非対応の従来法と提案法の加熱 特性の比較を行う。図 12 に従来法の回路で測定した加熱特 性を示す。ステンレスは抵抗率が高いために温度上昇が見 られるが，抵抗率の低いアルミニウムと銅は温度上昇がほ とんどみられない。これは, 市販されている卓上型 IH クッ

表 1 各種金属負荷の物理定数

Table 1. Physical constant of metal loads.

\begin{tabular}{c|c|c|c|c}
\hline Metals & $\begin{array}{c}\text { Specific Heat } \\
{\left[\mathrm{Cal} / \mathrm{g} \cdot{ }^{\circ} \mathrm{C}\right]}\end{array}$ & $\begin{array}{c}\text { Thermal Conductivity } \\
{\left[\mathrm{Cal} / \mathrm{cm} \cdot{ }^{\circ} \mathrm{C} \cdot \mathrm{sec}\right]}\end{array}$ & $\begin{array}{c}\text { Resistivity } \\
{[\mu \Omega \cdot \mathrm{cm}]}\end{array}$ & $\begin{array}{c}\text { Penetration Depth } \\
{[\mathrm{mm}] \circledast 40 \mathrm{kHz}}\end{array}$ \\
\hline Stainless & 0.110 & 0.039 & 73.7 & 2.159 \\
Aluminum & 0.215 & 0.530 & 2.75 & 0.417 \\
Copper & 0.092 & 0.940 & 1.72 & 0.330 \\
\hline
\end{tabular}




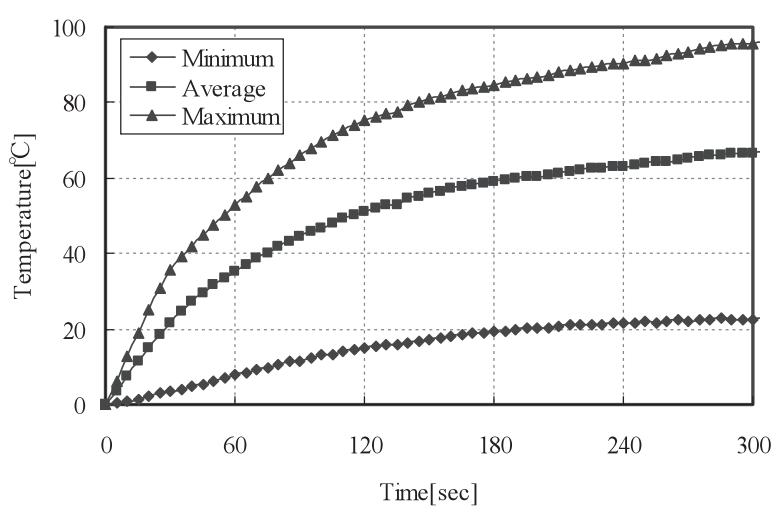

(a) Stainless-SUS304

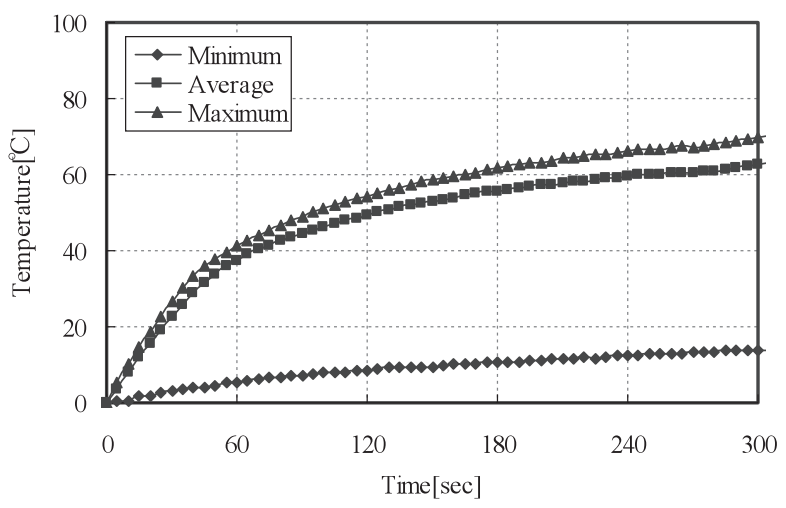

(b) Aluminum-A1015

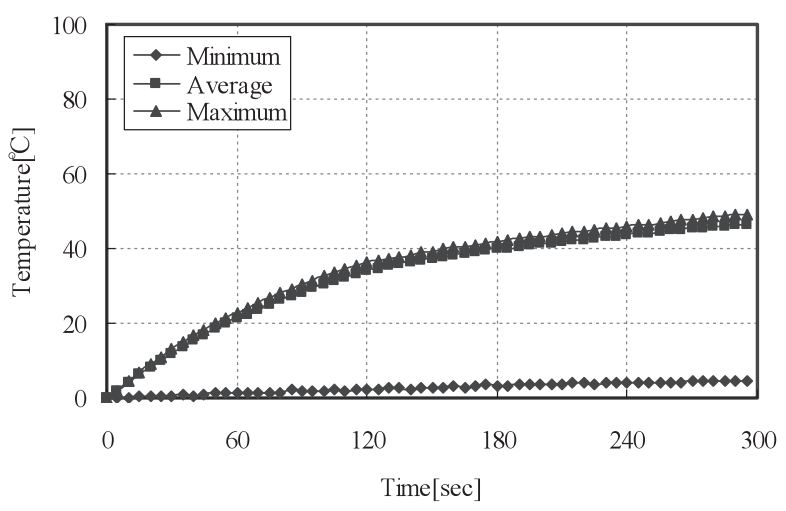

(c) Copper- $\mathrm{C} 1100$

図 11 各種金属負荷の温度上昇

Fig. 11. Temperature rise of various metal loads.

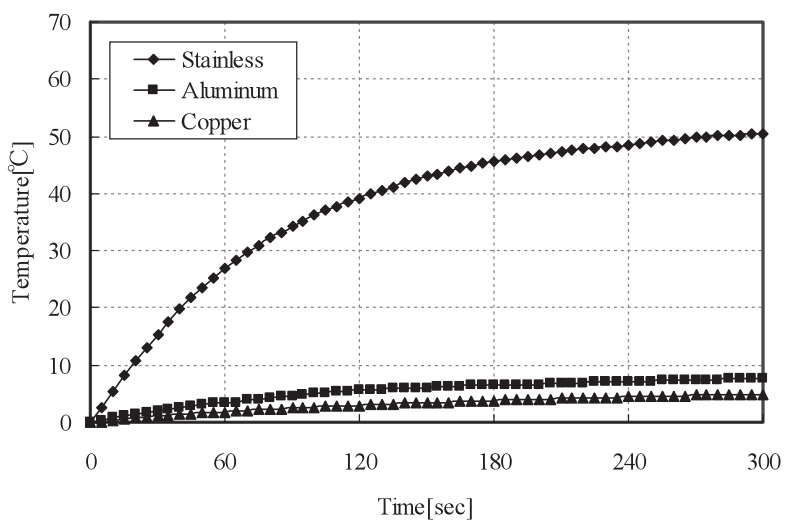

図 12 従来法による加熱特性 (平均值)

Fig. 12. Temperature rise by existing method (Average).

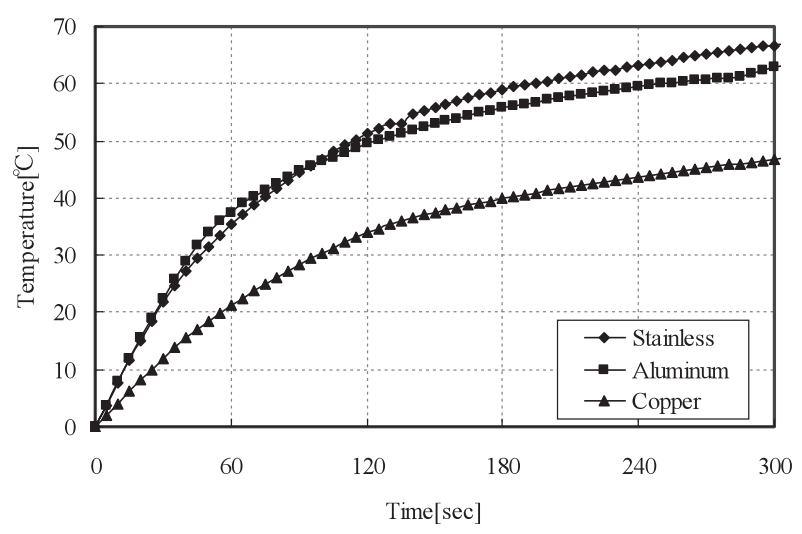

図 13 提案法による加熱特性（平均值）

Fig. 13. Temperature rise by developed method (Average).

キングヒータで使用できる金属の種類と一致している。

図 13 に提案法の回路で測定した加熱特性を示す。従来 法に比べて全ての金属負荷において大幅な温度上昇が得ら れている。ステンレスにおいては最高温度が $15^{\circ} \mathrm{C}$ も向上 している。さらに, 従来法ではほとんど加熱しなかったア ルミニウムにおいて提案法では最高温度上昇が $60^{\circ} \mathrm{C}$ を超 えている。銅も $45^{\circ} \mathrm{C}$ を超えており提案法の効果を明白に 示す結果となった。

以上により, 従来法では加熱できなかったアルミニウム と銅が加熱コイル電流の周波数は同じであっても提案法に よれば加熱できることを明らかにできた。

\section{7. まと め}

本論文では，二重コイルによって発生した高周波渦電流 により加熱するオールメタル対応 IH クッキングヒータの 実現について，その構成法を提案し，実験により加熱特性 を明らかにした。加熱コイルを金属負荷に対して二重に配 置し，それぞれに 180 度位相の異なる電流を流すことでス イッチング周波数の 2 倍の高周波渦電流が発生可能である ことを明らかにした。この効果により，金属負荷の表皮効 果が顕著になり，低抵抗率である金属の加熱が可能である ことを明らかにした。本提案法によれば，極細の線を多く 束ねて実現していたオールメタル対応装置用の加熱コイル が, 従来から使用されている線径の加熱コイルでオールメ タル対応が実現できる。したがって，加熱コイルの製造に 特別な注意を必要とせずコスト高にならない。さらに，駆 動回路が 2 組み必要という欠点はあるが, パワーエレクトロ ニクス回路で実現可能である最高周波数を 2 倍にして利用 できる大きなメリットがある。つまり，IH クッキングヒー 夕に限らず産業用誘導加熱装置にも応用できる画期的な方 法である。今後, 回路の最適制御法や商用電源運転時の詳 細な加熱特性を明らかにして，二重コイル駆動型のオール メタル対応 IH クッキングヒータのシステム構築を目指す。

(平成 18 年 3 月 23 日受付，平成 18 年 9 月 20 日再受付) 


\section{文献}

（1）近藤信二：「家電製品の最近の動向-IH 調理器ゆオールメ夕ル対応 $200 \mathrm{~V}$ IH クッキングヒータの開発」,社団法人 日本電機工業会 機関 紙「電機」 $2004 \cdot 12$, pp.31-34 (2004)

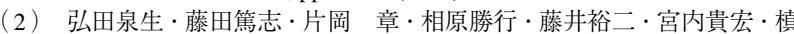
尾信芳:「オールメタル対応 IH クッキングヒータの開発と商品化」, 独創性を拓く先端技術大賞, 第 17 回優秀論文産経新聞社賞 (2003)

(3) I. Hirota, H. Yamashita, H. Omori, and M. Nakaoka: "Historical Review of Electric Household Appliance using Induction-Heating and Future Challenging Trends", IEEJ Trans. FM, Vol.124, No.8, pp.713-719 (2004-8) (in Japanese)

弘田泉生 · 山下秀和 · 大森英樹 · 中岡睦雄 : 「誘導加熱応用家電機器 の歴史と今後の技術課題」, 電学論 A, 124, 8, pp.713-719 (2004-8)

（4）小林 幹・米盛弘信：「誘導加熱装置」, 特願 2005-260326, 工学院大 学 (2005)

(5) H. Yonemori and M. Kobayashi: "Development of IH Cooking Heater Corresponding to the All-Metal Using Double-Coil", IEEJ, SPC-05-111, LD05-68, pp.1-6 (2005) (in Japanese)

米盛弘信・小林 幹:「二重コイルを用いたオールメタル対応 IH クッ キングヒータの実現」, 電学半導体電力変換・リニアドライブ合同研 資, SPC-05-111, LD-05-68, pp.1-6 (2005)

（6）原田耕介：「ソフトスイッチング電源技術」, 日刊工業新聞社 (1999)

(7) H. Omori, H. Kominami, M. Nakaoka, and T. Maruhashi: "A Control System in Single-Ended Voltage-Fed Resonant Inverter for Induction-Heating", T. IEE Japan, Vol.107-D, No.4, pp.487-494 (1987-4) (in Japanese)

大森英樹・ 小南秀之 - 中岡睦雄・ 丸橋 徹: 「誘導加熱調理器用電圧 形共振 1 石インバータの制御システム」, 電学論 D, 107, 4, pp.487-494 (1987-4)

(8) H. Omori, H. Kominami, M. Nakaoka, and T. Maruhashi: "Circuit Design of Self-Controlled Single-Ended Resonant Inverter for Induction Heating", T. IEE Japan, Vol.107-D, No.11, pp.1371-1378 (1987-11) (in Japanese) 大森英樹 - 小南秀之 ·中岡睦雄 - 丸橋 徹 :「誘導加熱用自制御式 共振 1 石インバー夕の回路設計」, 電学論 D, 107, 11, pp.1371-1378 (1987-11)

(9) T. Tanaka: "A New Induction Cooking Range for Heating Any Kind of Metal Vessels", IEEE Trans. Consumer Electronics, Vol.35, No.3, pp.635641 (1989)
（10）福持泰明：「第 14 章 IGBT の IH 炊飯ジャーへの応用」, トランジスタ 技術 SPECIAL No.54, 特集 実践パワー・エレクトロニクス入門, CQ 出版社, pp.139-146 (1996)

（11） 高橋勘次郎・深町成一・渡辺哲哉・久保田喜郎：「高周波の工業への 応用一誘導加熱・誘電加熱・超音波一」, 東京電機大学出版局, pp.1-8 (1977)

（12）稲葉 保:「パワーMOS FET 活用の基礎と実際」, CQ 出版社, pp. 285302 (2004)

米 盛 弘 信 (学生員) 1982 年 9 月 21 日生。 2003 年 3 月育

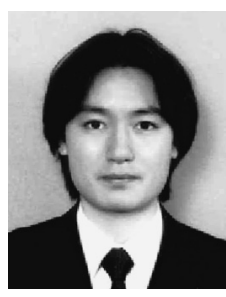
英工業高等専門学校電子工学科卒業。2005 年 3 月電気通信大学電気通信学部電子工学科卒業。同 年 4 月工学院大学大学院工学研究科電気・電子工 学専攻修士課程入学。2004 年 4 月育英（サレジ 才）工業高等専門学校電子工学科非常勤講師。現 在に至る。主として, 電力変換回路, 電子回路の 研究に従事。電気設備学会, パワーエレクトロニ クス学会, IEEE の各学生員。2006 年第 24 回電気設備学会全国大会 発表奨励賞受賞。

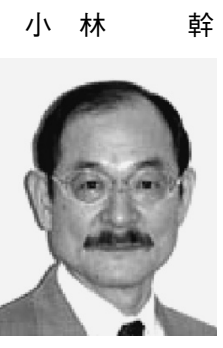

幹（正員） 1942 年 6 月 11 日生。1967 年 3 月明治 大学大学院工学研究科電気工学専攻修士課程修了。 工学博士。工学院大学助手を経て同大学電気工学 科と電気システム工学科の主任教授を兼務。主に 電力変換回路と自然エネルギーに関する研究に従 事。現在は，文部科学省の学術フロンティアに採 用されて電気設備の耐震性能向上に関する研究に 従事。電気設備学会 2001 年度論文賞受賞。電気 設備学会，IEEE などの各会員。 